\title{
THE LONG TERM PRESERVATION OF AN 18TH CENTURY GENE BANK HERITAGE - CASE STUDY OF THE SZÉCHENYI LIME TREE ALLÉE AT NAGYCENK
}

\author{
GERZSON, L. - SZILÁGYI, K.* - BEDE-FAZEKAS, Á. \\ Corvinus University of Budapest, Department of Garden and Open Space Design \\ 1118 Budapest, Villányi út 29-43., Hungary \\ (phone: +36-1-482-6288) \\ *Corresponding author \\ e-mail: kinga.szilagyi@uni-corvinus.hu \\ (Received $3^{\text {rd }}$ November 2011; accepted $23^{\text {rd }}$ November 2011)
}

\begin{abstract}
The allée is one of the oldest instruments and forms of landscape architecture, which has often been used from the Antiquity for the expression of visual and functional relationships, for the delimitation of space, or for the pictorial creation of movement. The several hundred years old allées of the late baroque age, which still live among us as the witnesses of bygone times, represent a special value throughout Europe. The longevity and the respectable size as such bestow a certain value upon the trees. However, the allées also stand for a garden art, landscape, culture historical and natural value, which in a summarized way are called cultural heritage. Furthermore, the gene pool of the proven longevous, high tolerance tree specimens is a natural and genetic heritage of scientific signification. The age of the trees and allées is finite. Even with a careful and professional care, the renewal is inevitable, which, beyond technical problems of landscape architecture might raise many scientific, nature conservation, yes, esthetical and ethical questions. This is why there is no universal methodology, but there are aspects and examination procedures of general validity with the help of which a renewal can be prepared. The renewal concept of the lime tree allée in Nagycenk aims at the protection and the transmission of the value-ensemble embodied in the allée. One part of the value-ensemble is the spiritual, cultural heritage, the extraordinary value of the landscape-scaled, landscape architectural creation planted and taken care of by the Széchenyis. On the other hand the two and a half centuries old trees represent an inestimable botanical and genetic wealth. Its transmission and preservation is a scientifically important program coming up to the Széchenyi heritage. After the registration of the originally planted old trees, the complete nursery material of the "Széchenyi limes" necessary for the replanting can be produced by vegetative propagation. The gradual replacement of the stand with its own propagation material, by the carefully raised nursery trees of the same age can be a model for the gene-authentic renewal method - a novelty even at an international level.
\end{abstract}

Keywords: historic allée, preservation of gene bank heritage, nature conservation, renewal and protection of cultural heritage

\section{Introduction}

The almost $2.3 \mathrm{~km}$ long double lime tree allée in Nagycenk is a national culturehistorical, landscape architectural and natural value, which we inherited from the $18^{\text {th }}$ century. According to the old travelers, the grandiose allée, initially planted with 600 small-leaved lime trees, counted as an outstanding allée amongst the landscape architectural creations of the late baroque estates of the nobility. "The beautiful castle and the garden with the orangery are a property of count Széchenyi. From the garden, there is an allée of 600 limes lasting for almost five quarters of an hour leading to a small grove on a hill." This is what Gottfried Edlen von Rotenstein (1783) wrote, who made notes of his travels to Hungary in the $1760 \mathrm{~s}$ and who is also quoted by Rapaics (1940). 
The allée was part of the Széchenyi estate in Nagycenk and represents an organic northward continuation of the castle garden, way out until the high shore of the Lake Neusiedl. The allee is today part of the administrative territory of three municipalities, besides Nagycenk that also hosts the castle, the larger part is reaching along the territory of the village of Hidegség, while the small grove terminating the allee, and in it the shrine of Hanna Erdődy and Béla Széchenyi already belong to the municipality of Fertöboz. It is thus justifiable to call the allée the Széchenyi lime tree allée, since this name does not only solve the "municipality conflict", but it also denominates the creator and the owner, the Széchenyi family, a Hungarian noble family of an incomparable high-thinking, whose members once gave an example not only in the development of their property, but also in that of the entire country.

\section{Review of literature}

The Nagycenk estate became the property of the Széchenyi family at the beginning of the $18^{\text {th }}$ century. Count Antal Széchenyi began the development of the estate and the construction of the castle in the middle of the 1700s. The allée has been, according to family memories, planted by his wife, Zsuzsanna Barkóczy between 1754 and 1760 as a continuation of the main axis of the baroque garden, on the opposite side of the main road, way up until the high shore of the Lake Neusiedl (Örsi, 1976; Örsi, 1992). On the first military survey (1783-85), the lime tree allee has already been represented as a significant landscape element (Fig. 1). On the cadastral map of Hidegség from the middle of the $19^{\text {th }}$ century (1856), not only the proportions and the planting order of the allée can be seen, but also the fact that the lime tree allée ends before the small grove on the high shore of the Lake Neusiedl; from this point, the allée is continued until the terminating grove by a much narrower allée, of a different mode of representation, planted with trees of a smaller canopy, thus of a different species. The grove housed a hermitage for a short time and the small chapel attached to it, this way the termination of the allée, its close, has also been reinforced. Unfortunately no documents have been found yet about the allée leading through the grove, so we can only assume that this might have been a fruit tree allée. This is also indicated by the planting distance, which is 3 fathoms, that is $5.68 \mathrm{~m}$, and the function of the hermitage also supports this idea. The first inhabitant of the hermitage settled down here in 1773, the chapel was built in 1774 (Kelemen, 2011). The hermitage was torn down quite early, but the chapel stood there until the beginning of the 1900s. The Széchenyi allée, extraordinarily imposing even among the other allées typical for the ensembles of baroque gardens and landscapes, figured in almost every contemporary travelogue and property description, like for instance in the garden description of great garden historical value by Rajmund Rapaics from the beginning of the $20^{\text {th }}$ century, which then mentioned an allee of 567 small-leaved lime trees, each of 3-4 m trunk girth (Rapaics, 1940).

Miksa Földváry and Károly Kaán drew attention to the natural, culture-historical, and landscape architectural merits of the lime tree allée in Nagycenk already in the 1930s (Földváry, 1934), until the Royal Hungarian Minister of Agriculture declared it a nature conservation area with its $80.855 / 1942$. decree. According to the valid conservation decision, the allée is primarily a natural monument, where the old, often rotting, hollow trees are home to many protected species (xylophagous insect, bats and birds). 


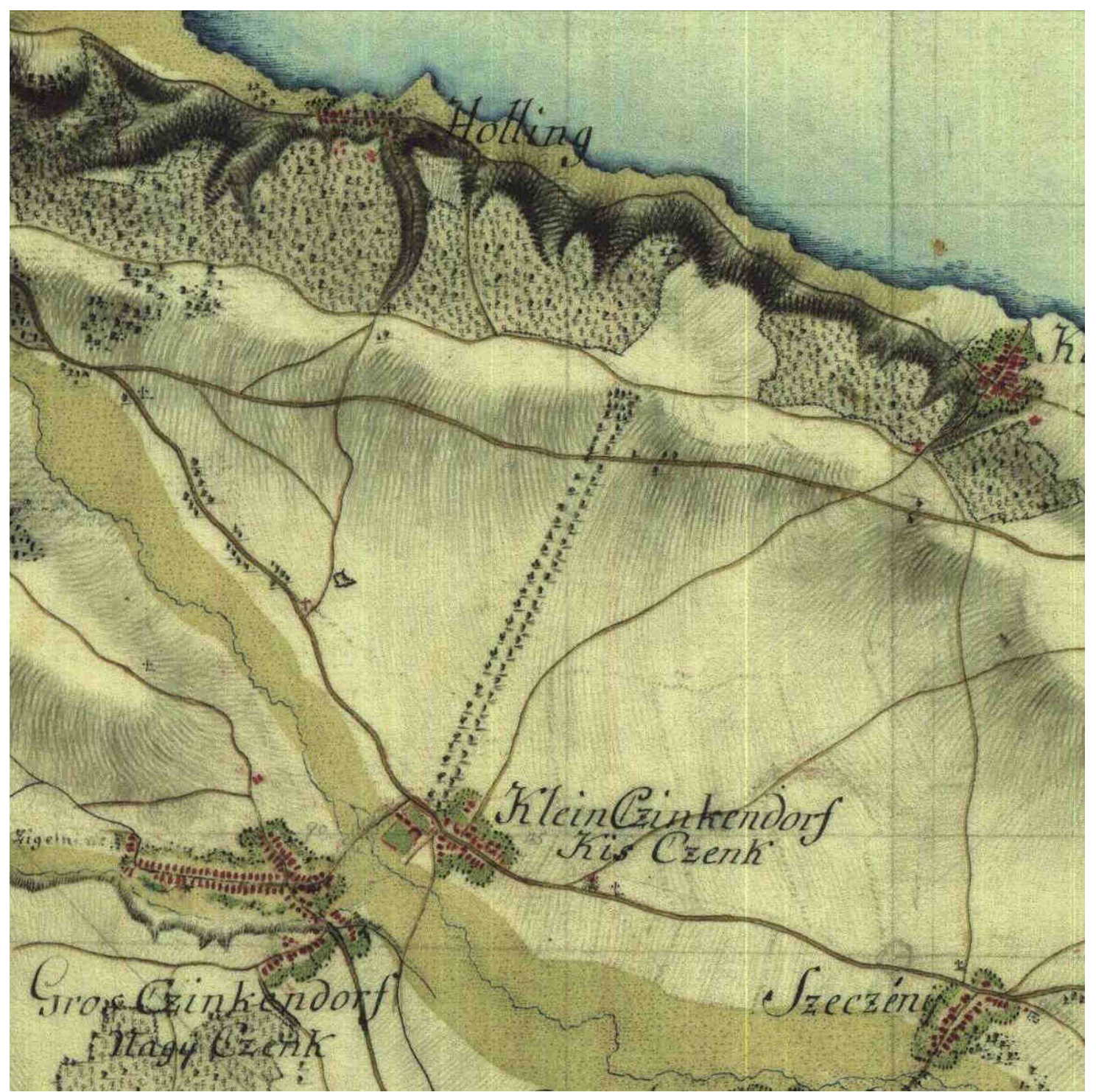

Figure 1. Nagycenk and its surroundings on the first military survey (1780-1784 IV/5). At this time, the Széchenyi lime tree allée is recorded as a characteristic landscape element.

The protection today has several levels, since the allée (at least its segment in Nagycenk), along with the castle, is considered from 2001 on a monument and a world heritage (Fig. 2). Among the Hungarian protected allées there is no one of similar value from those that belong to castle gardens; we might only mention here the similarly landscape-scaled black pine allée in Keszthely, which has been planted much later as a creation of Tasziló Festetics.

Concerning the original length of the allee and the number of trees various sources impart different data, but the ones conferred by Rapaics (1940) mentioning 600 specimens in the approximately $2.3 \mathrm{~km}$ long allée, with a 4 fathom $(7.58 \mathrm{~m})$ planting distance between the trees seem to be acceptable. The distance between the two rows was 12 fathoms $(22.75 \mathrm{~m})$. Here Rapaics indicates 23 meters and 7 meters as a planting distance, but this can by no means be considered accurate, since back then instead of metric units fathoms were used in measurement. 


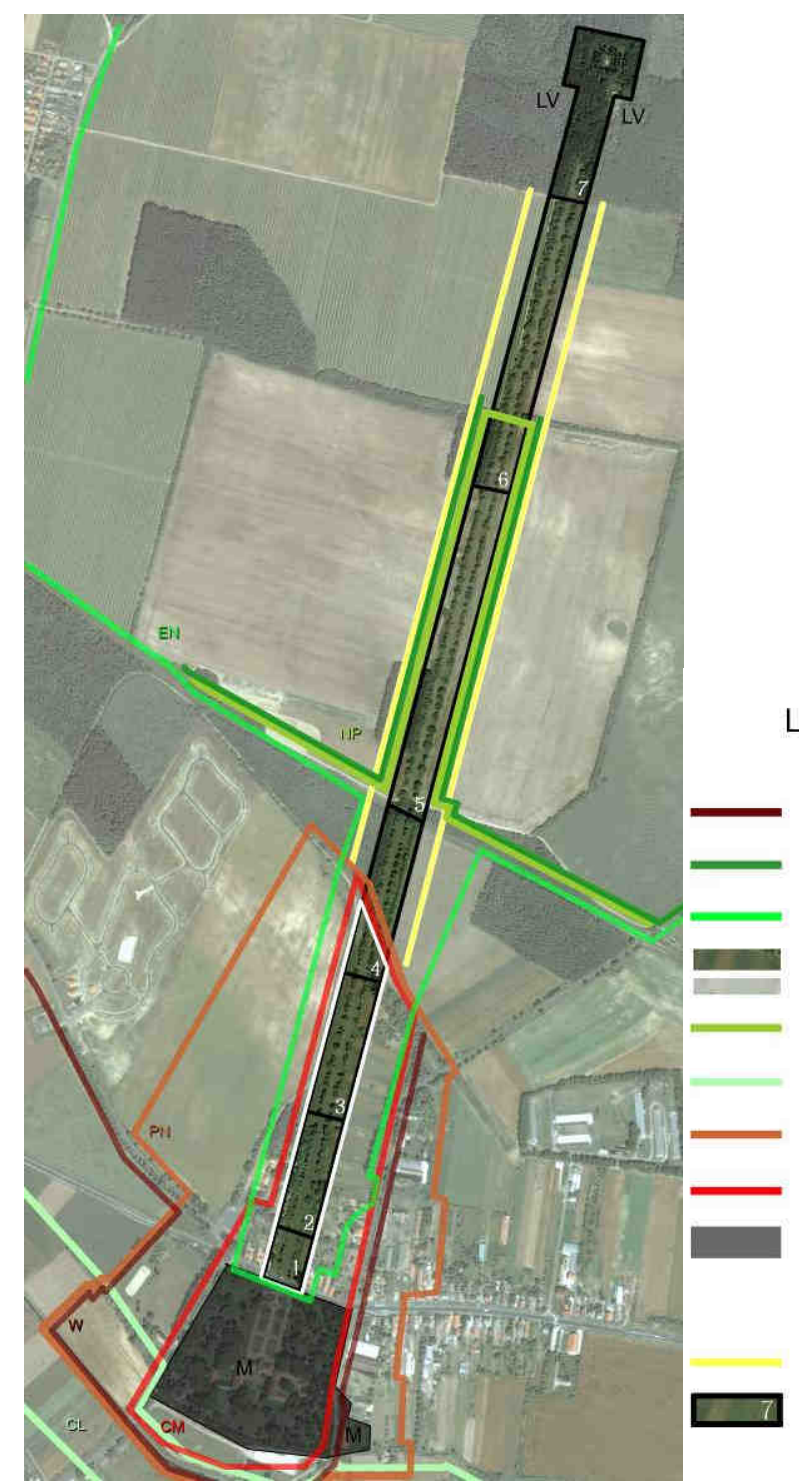

\section{LEGEND}

W WORLD HERITAGE

NATURA 2000 AREA

EN NATIONAL ECOLOGICAL NETWORK

NATIONAL CONSERVATION AREA

NATIONAL PARK

CONSERVATION AREA OF LOCAL INTEREST

PROTECTED NEIGHBOURHOOD OF MONUMENT

CONSERVATION AREA OF MONUMENT

MONUMENT, MONUMENT PARCEL

LV INDIVIDUAL LANDSCAPE VALUE - SPOT

INDIVIDUAL LANDSCAPE VALUE - LINE

SECTIONING OF AVENUE

Figure 2. An about $2.3 \mathrm{~km}$ long segment of the allée with the indication of the different levels and types of protections (edited by Dora Hutter)

The double allée proves to be a typical example of the so called "allée verte", in the middle of which there is a turf field, and people only have trodden a path on its two sides. Thus the allée cannot be considered a greenway in the traditional sense, where there would have been regular riding, horse-carriage, wagon and pedestrian traffic (Fig. 3). The allée was pastured: documentations show that sometimes even the stud was out at feed here and there are pictures representing the practice of the pasturage by sheep flocks. The old postcard testifies that until the bottom of their canopy, the intermediate spaces of the trees were kept clear and transparent. We can take it for granted that the family of the count also used this allee for riding their horses, probably regularly until the construction of the railroad (Fig. 4). 


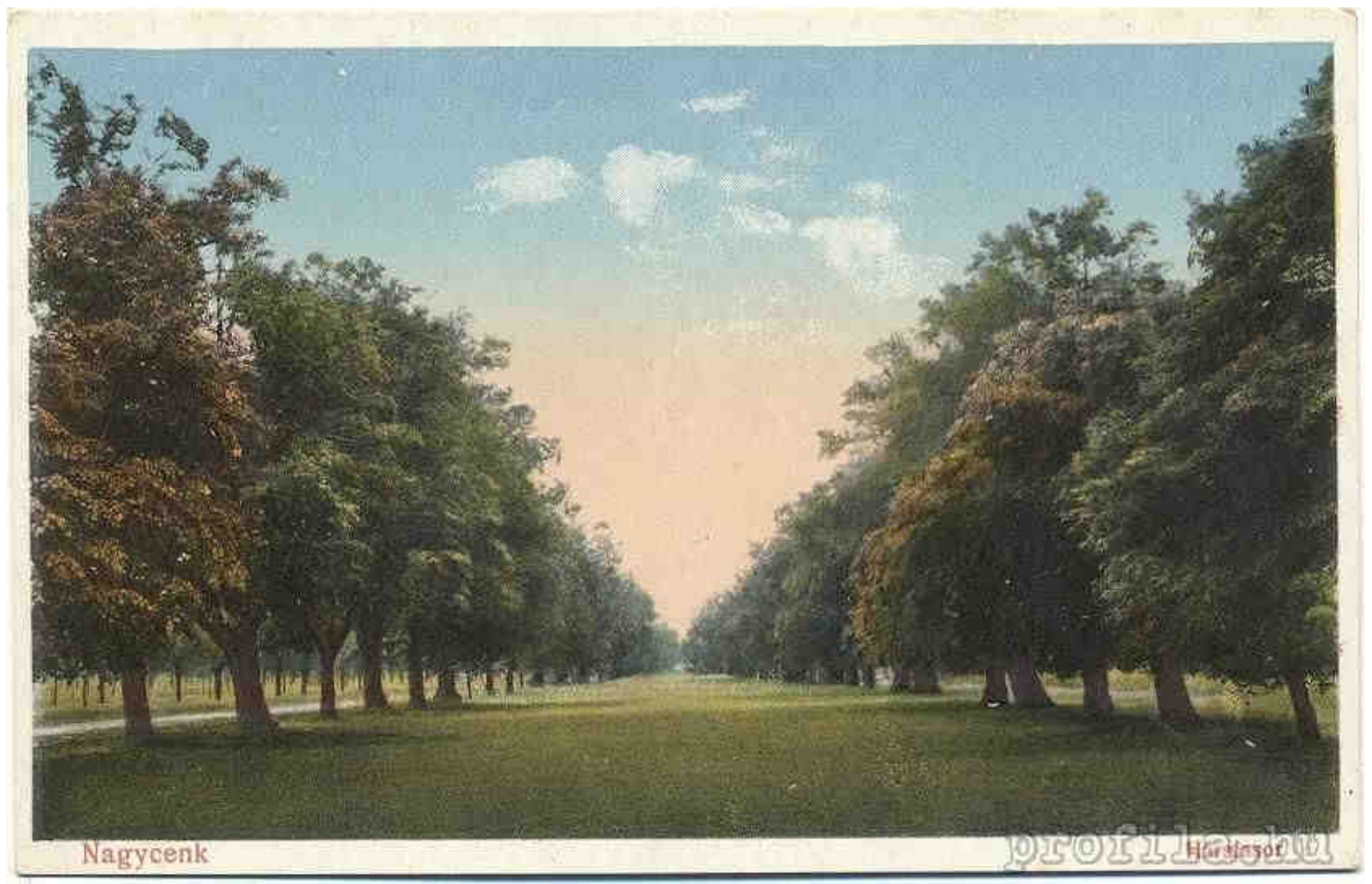

Figure 3. As shown by the postcard from the end of the $19^{\text {th }}$ century, the greenway of the allee was not, or rarely used (around 1890, source: http://www.profila.hu)

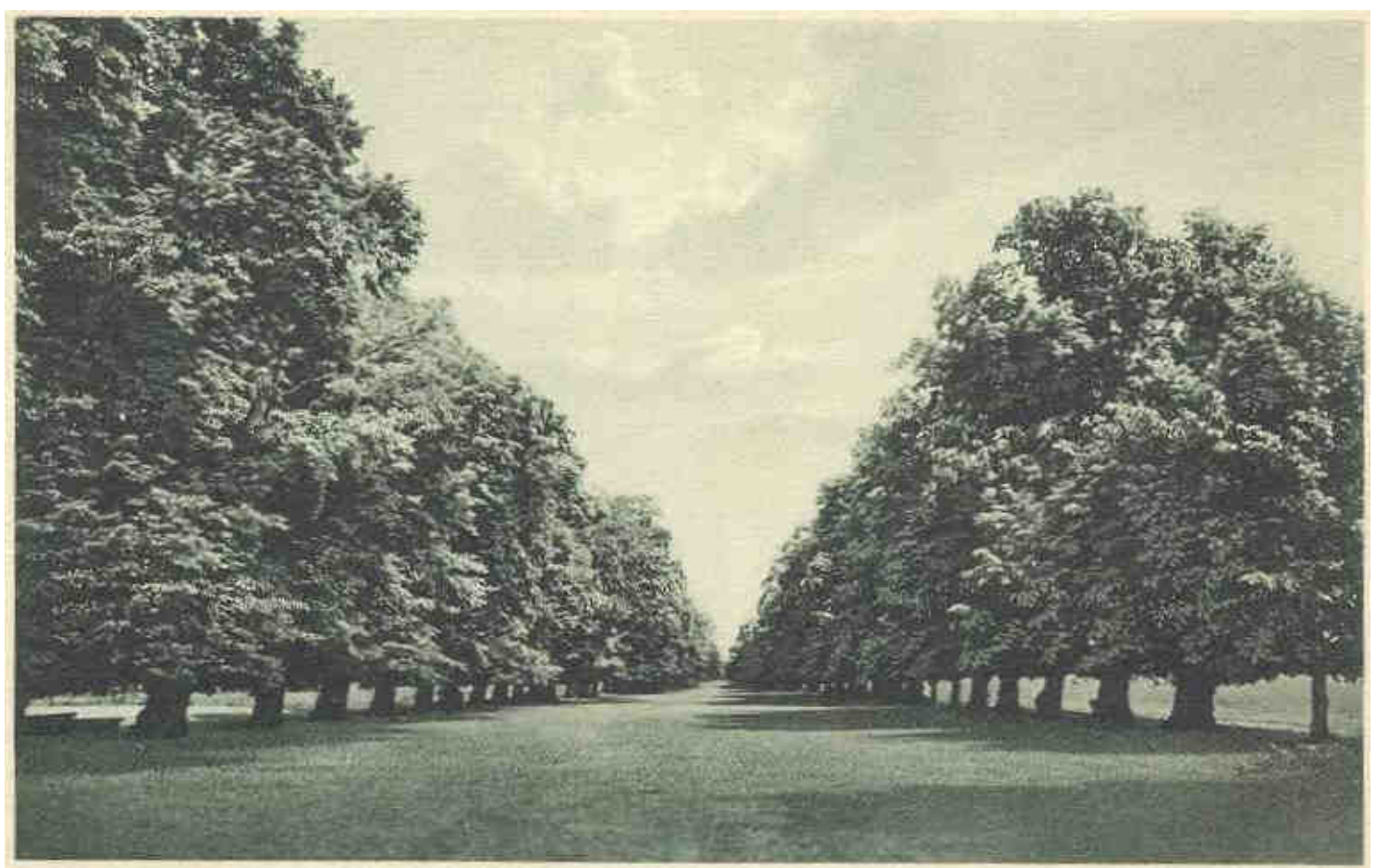

Figure 4. According to the old postcard showing the Széchenyi allée, the space between the trees was once maintained by pasturage (around 1920, source: http://www.profila.hu) 
The Széchenyi lime tree allée can be considered one of the most important among the numerous extraordinarily significant landscape architectural and dendrological values in Hungary. Its historical and culture-historical value is enhanced by its connection to the Széchenyi family who planted and used it. Its landscape architectural and esthetical specialty has its source in the monumentality of the whole ensemble, and the fascinating beauty of the individual specimens. Its scientific significance and its nature conservational value is evident from the inestimable research value of the living gene bank (genetic reserve) composed of the documented, at least 250 years old specimens. The preservation of this extraordinary national value is equally necessary from a scientific, ethical, historical and touristic aspect; it is a priority task that requires a joint effort of monument protection and nature conservation.

The Tanulmányi Erdőgazdaság (Practicing Forestry) Zrt., in charge of the maintenance of the allée, has since 2002 a nature conservation management plan available (upon the order of the Fertö-Hanság National Park Directorate the management plan has been prepared by the Department of Botany of the University of West Hungary and the Department of Landscape Protection and Rehabilitation of the Szent István University). The management plan aims at the prolongation of the life of the old lime trees by 50-60 years, and at the same time the gradual renewal of the allee (Csima and Módosné Bugyi, 2003). Yet the management plan does not reject the idea of the complete exchange of tree species either. Instead of the actual small-leaved lime (Tilia cordata) it suggests the large-leaved lime (Tilia platyphyllos) already used for substitution in the beginning of the 19th century or the hybrids of the two species (T. cordata and T. platyphyllos), and it theoretically does not reject the planting of silver lime (T. tomentosa) either, which is very different and incompatible with the landscape (smaller with a different canopy shape thus not matching the original planting system either).

The plan suggests many actions for the protection of the allée, including the designation and maintenance of a freely unfolding protection zone along the allee, free of any buildings and competing plant stands, as well as the individual, that is, horticultural care of the trees. The regular allée-cleaning, maintenance, tree treatment works included in the management plan are - unfortunately - not carried out at all, and there is a risk that the old trees might collapse in a rapid succession.

An allée of such a great culture-historical value deserves particular attention; everyone agrees in that, in this subject, all concerned scientific circles, professional associations and authorities represent the same standpoint. However, opinions about the protection methodology vary. Partly because the monumentality of the task furnishes everyone with food for thought, primordially because of the putative impossibility of its completion within a reasonable time. Although there is a possibility that can simultaneously preserve and transmit the culture-historical, landscape architectural, monumental and natural values to posterity. There is a need for a novel allée renewal methodology, which has never yet been applied in our country, which allows for the safeguarding and the renewal of all these values, so that the imposing allée created by the Széchenyis can once again appear as a uniform picture - keeping its original character, ambience, culture-historical value, even its gene pool. Nevertheless, the renewal can only be fruitful through an extensive social collaboration, exclusively based on the carefully defined professional criteria, taking into account the specific characteristics of the group as a whole and of the individual plant specimens (trees) as 
well as those of the site. This methodology is the authentic allée renewal using the same genes, which has to be carried out in stages and according to a long-term schedule.

The originally planted specimens of the lime tree allee in Nagycenk are small-leaved limes (Tilia cordata Mill.). It is a seedling population, the propagation material of which might have been collected from the seminiferous trees of the surrounding forests or parks. Whether they are the seedlings of one or more trees that can be clarified by genetic studies. This detail is also important because such an investigation, in the case of favourable results, might reveal a field of the $18^{\text {th }}$ century Hungarian horticulture, which has been quite ignored until now, the propagation of ornamental trees and their nursery raising, that is, we can get an idea of the beginnings of the Hungarian ornamental nursery cultivation. A complication with these genetic studies is that while the genetic mapping of our important industrial crops and the marking serving the identification of the genes is solved, no such investigations have been carried out for the limes, which means that even the necessary basic research for the gene identification has to be done. We have already started our research in this field.

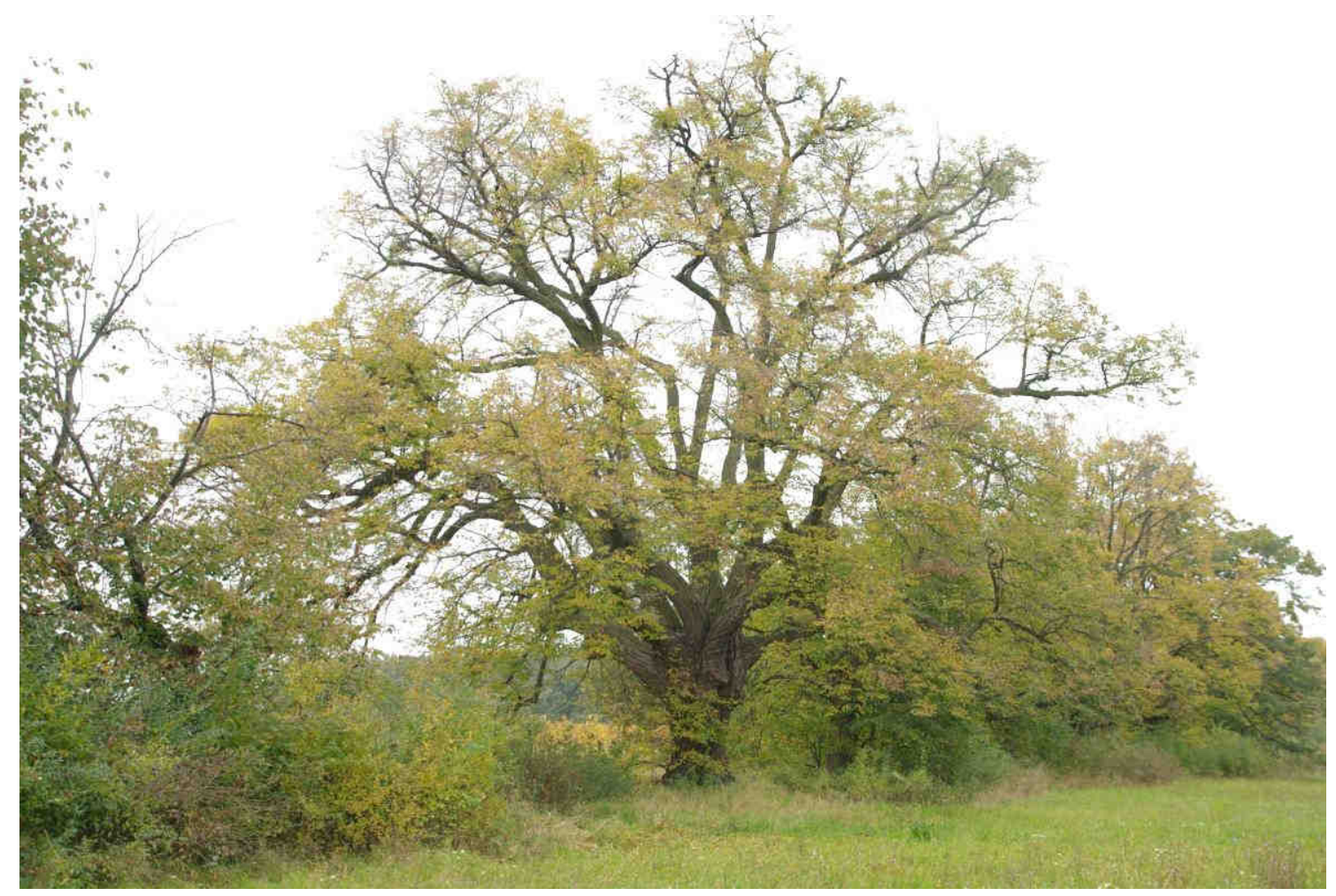

Figure 5. A specimen of nice canopy, growing in an open space without competitors (photo: L. Gerzson)

According to its role in plant communities, the small-leaved lime is a so-called precursor species, that is, its genetically encoded life expectancy is shorter than that of the climax species building a population on the given territory (Soó, 1973) This is why in the case of small-leaved limes one cannot count on the survival of such record-sized and very old specimens as in the case of oaks and beeches, of which many several hundred years old specimens are known countrywide, being a subject to many legends. The small-leaved lime specimens of over 150 years are considered very old, in closed forest communities they hardly ever reach that age; when in parks or in a row, they are 
often fallen because of the hazardousness resulting from their decaying branch system and their reducing esthetical value even before they reach this age. Only independently positioned specimens growing in open spaces, without competitors can survive at this age as a showy, beautiful tree (Fig. 5). The good quality, uniform genetic material, the favourable environmental conditions (soil characteristics, exposure and precipitation) and the lack of competing vegetation - which is first of all due to the probably longlasting professional and intense management and care - might offer an explanation for the extraordinary age of the lime trees in Nagycenk. Way until the $20^{\text {th }}$ century, the maintenance of the allée and its environment was carried out in a very simple and economic manner, by pasturage. The flocks of sheep most suitable for this task can do a very "thorough and meticulous" work and thus the area to be maintained - the allee and its environment - turned into a lucrative unit of the Széchenyi property without raising the maintenance costs. The fact about the pasturage is not a mere assumption, this is also testified by the photos from the beginning of the 1900s (Fig. 6). After (or even before) the successful renewal of the allee it would be also worthwhile to dedicate a thought to the revitalization of the maintenance of the area by pasturage.

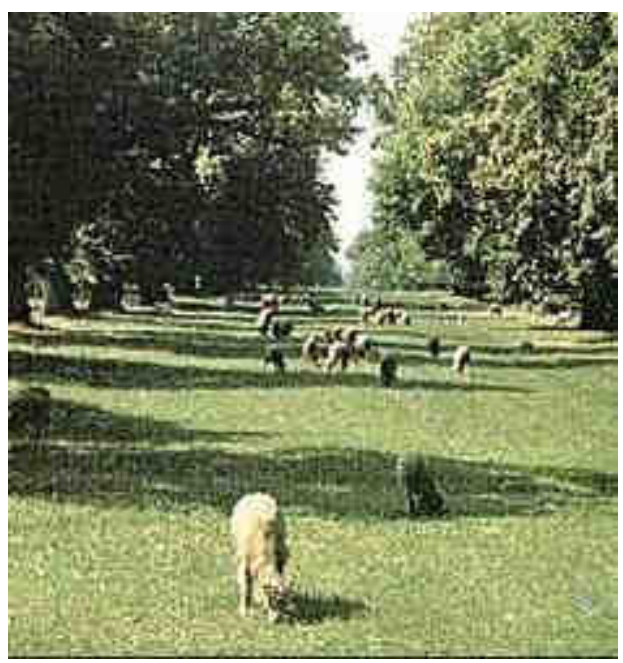

Figure 6. Once, the pasturage by sheep played an enhanced role in the maintenance of the Széchenyi lime tree allée, which still appears to be a good solution after its renewal. (around 1930, source: http://www.szikszi.sulinet.hu/nevado/szechenyi.htm)

\section{Materials and methods}

In spring 2010 we made a site visit. At that time it was obvious that the majority of the old specimens of the allée is in very poor health conditions, their branches breaking, decaying, many of them very close to complete degradation. During the years, numerous specimens died, indeed, many of them have already been replaced during the last decades. Thus, among the old trees of the allee we can find 30-50 years old specimens and even young timberlings planted a couple of years ago (Fig. 7). These substitutions make a rupture in the uniform picture of the allée. At some parts of the allée, scrubs growing adjacently or spontaneously between the trees represent a competition, which is a further threat to the older trees. The earlier treated, cementsolidified trees deteriorated even more, this procedure did not stand the test of time. The old, sick trees are doomed to a total degradation unless professionally taken care of. 
Even a good tree care and treatment could do nothing but extend this agony and this work could only be carried out at very high costs, with the contribution of wellexperienced experts during the course of many years. By contrast, the condition of the allée shows that there has been no substantial and professional maintenance work carried out for years.

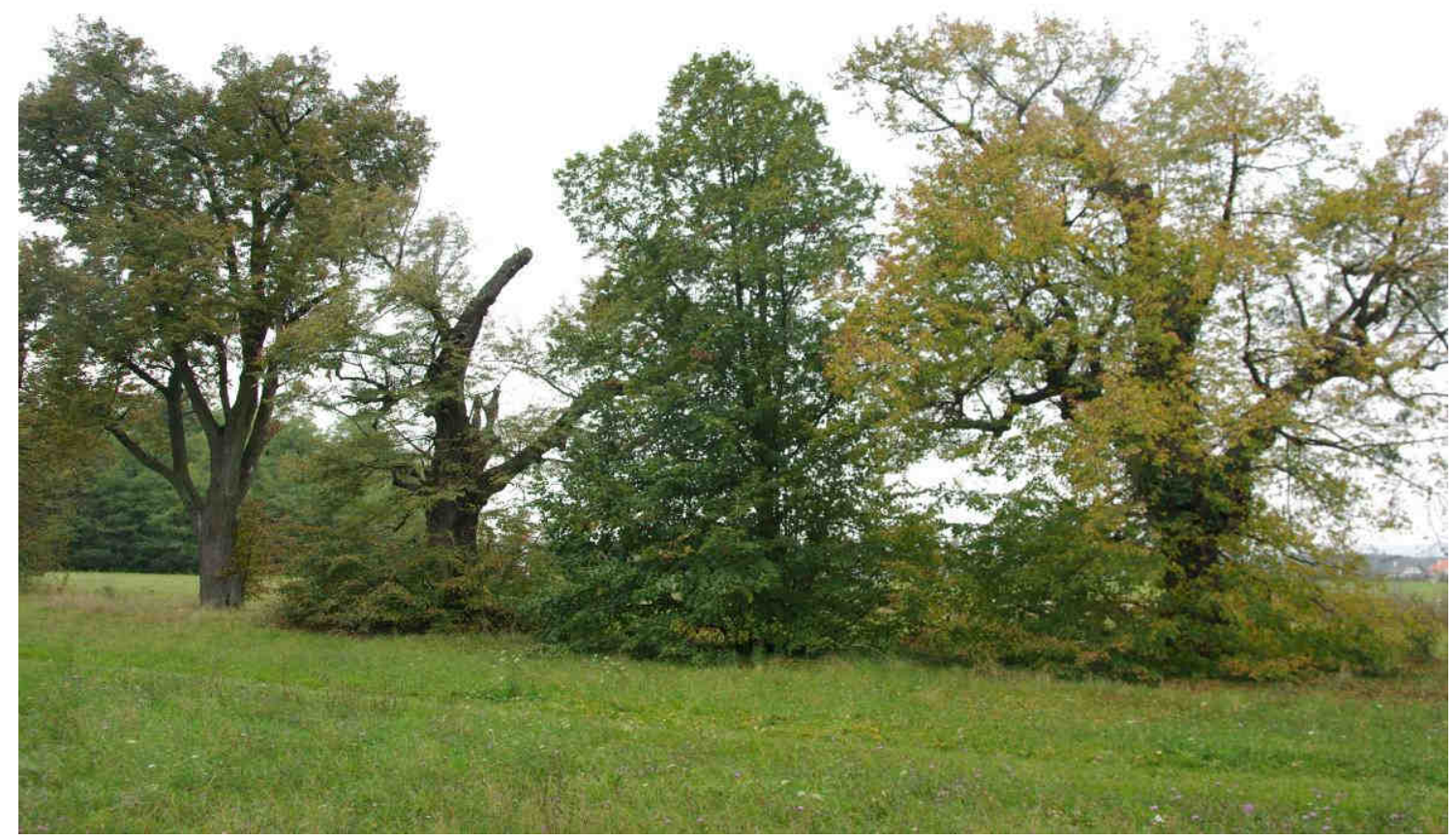

Figure 7. In some parts of the allée there is an ensemble of trees in good condition or decaying old ones, as well as healthy young plants and empty tree spaces (photo: L. Gerzson)

The renewal of the allee is not to be delayed on the one hand because of the condition of the trees - in many cases standing close to total degradation - on the other hand due to the long time required for the renewal. The renewal of the allée can namely only be accomplished in a way that protects the spirituality, the "genius loci" manifested in the individual trees and in the allée as a whole, so that it can be experienced and perceived by everyone. This requires a renewal program that takes on the spirituality.

The spiritual background or the basis of the renewal program is that these very old, even in their degradation beautiful trees "have seen" the Széchenyis, when these took a walk there, passed by, rode their horses along and among the trees, and at the sight of the imposing allée you can feel the spirituality of the masterminds Ferenc and István Széchenyi. Thus the renewal of the allée can only be conceived with the salvage of this "wood material". And since the characteristics and environmental conditions of the landscape have not changed considerably, the small-leaved lime will still find here a favourable habitat and living conditions, although there is no doubt that the $20^{\text {th }}$ century has brought important changes to the environment of the allee in many aspects. The intensive farming, the road and railway constructions and other works of similar scale have changed the groundwater flows and the groundwater level. The shoreline of the Lake Neusiedl has moved, compared to earlier times, much further to the north. 
Although the allée has never been in direct contact with the lake, among many reasons due to the terrain conditions, but between the small grove terminating the allee and the shore there was only a distance of a few hundred meters, while nowadays it can be measured in kilometers. On the place of the former fishing colonies' activity, one can find roads, buildings, extensive reed beds and agricultural areas. It is quite certain that this ecological change has also contributed to the acceleration of the degradation process of the trees in the allée. There is no question however that the current environmental conditions are suitable for the survival of the small-leaved lime in this region, thus the allée planted with this species does not only have a past and a present, but a future as well.

During the renewal of the allée we can still count on appropriate habitat conditions for the lime trees, which means that there is absolutely no need to change the tree species. On the contrary, the necessary nursery propagation material for the renewal has to be produced from the here already present original plant species.

We have sized up and registered the existing plant stand of the allee in spring 2011. The registration took into account almost the whole length of the $2.3 \mathrm{~km}$ long Széchenyi allée, only omitting the short final segment, originally of a different planting system, where due to the forestation and the maintenance failures the place original trees and even the line of the allée can hardly be found. During the survey, we divided the double allée to an even (eastern) and an odd (western) side, the numbering started from the castle's (southern) side, and occurred along two principles: firstly the original planting spaces were numbered, then the "inter-plantations" which were implemented later (between the original tree spaces). We also numbered the original places even in the case when the tree itself on it had died or was not recognizable. Thus, at last, the tree cadastre takes over the function of a tree- and tree spot cadastre. During the definition of the original planting space, the former information (Rapaics, 1940) was very helpful, which revealed that the trees had originally been planted at a 4 fathom distance from each other. It is however important to mention - and this could also add some important detail to the studies investigating the historical context of the plantation - that the real spacing distance grew northwards, and thus based on the spacing distance the allée can be divided into three segments. We also verified the 12 fathom line spacing known from the literary source with on-site measurements.

Next to the number in the cadastre we indicated if the given specimen is still a living, existing one, if it was inter-planted, we also indicated its location by the distance measured from the next living specimen with original spacing preceding it in the number list. The estimation of the tree ages accurate to five years was also entered into the cadastre, and to the most probably originally planted specimens we indicated 250 years uniformly. Based on the health status we classified the living plants into 6 categories, where 1 stands for healthy free-growing specimens and 6 for those that only live on through their offshoots (Table 1).

Table 1. Health status categories applied during the tree-survey

\begin{tabular}{c|c}
\hline Category & Meaning \\
\hline 1 & Habit characteristic of the species, healthy \\
2 & Canopy in good condition, partially truncated \\
3 & Canopy in good condition, heavily truncated \\
4 & Deteriorated status, truncated \\
5 & Decaying \\
6 & Decayed trunk, only root or stem shoots \\
\hline
\end{tabular}


We also included in the cadastre the trunk girth and diameter, as well as the canopy diameter, and we also added a lot of written comments with respect to the canopy, branch system and the trunk (Table 2). We find it necessary to complete the cadastre by a new on-site survey, which can help to record further weaknesses and defects of the trees in other vegetation periods and thus complements the already existing data. There is also a need for the further broadening of the initiated photo gallery.

Table 2. A detail from the tree cadastre. The three consecutive specimens of the western allée: an inter-planted tree, a dead one and old one on its original spot.

\begin{tabular}{|c|c|c|c|c|c|c|c|c|c|c|}
\hline Number & Age & \multicolumn{5}{|c|}{ Health status } & \multicolumn{2}{|c|}{ Trunk diameter/girth } & \multirow{2}{*}{\multicolumn{2}{|c|}{ Trunk status: $\quad$ straight }} \\
\hline & \multirow{3}{*}{15} & \multirow{3}{*}{1} & \multirow{3}{*}{23} & \multirow{3}{*}{4} & \multirow{3}{*}{5} & \multirow{3}{*}{6} & $4 \mathrm{~cm}$ & $13 \mathrm{~cm}$ & & \\
\hline \multirow[t]{2}{*}{ K87 } & & & & & & & \multicolumn{2}{|c|}{ Canopy diameter } & \multirow[t]{2}{*}{ Canopy status: } & \multirow[t]{2}{*}{ one-sided } \\
\hline & & & & & & & & & & \\
\hline Distance & \multirow{2}{*}{\multicolumn{10}{|c|}{$\begin{array}{l}\text { Comments: } \\
\text { Place of eartag: }\end{array}$}} \\
\hline $3.60 \mathrm{~m}$ & & & & & & & & & & \\
\hline Number & Age & \multicolumn{5}{|c|}{ Health status } & \multicolumn{2}{|c|}{ Trunk diameter / girth } & \multicolumn{2}{|l|}{ Trunk status: } \\
\hline & & 1 & 23 & \multicolumn{3}{|c|}{456} & \multicolumn{2}{|c|}{ Canopy diameter } & \multicolumn{2}{|l|}{ Canopy status: } \\
\hline Distance & \multirow{2}{*}{\multicolumn{10}{|c|}{$\begin{array}{l}\text { Comments: } \\
\text { Place of eartag: }\end{array}$}} \\
\hline & & & & & & & & & & \\
\hline Number & Age & \multicolumn{5}{|c|}{ Health status } & \multicolumn{2}{|c|}{ Trunk diameter/girth } & \multirow[t]{2}{*}{ Trunk status: } & \multirow[t]{2}{*}{ cracks } \\
\hline \multirow{3}{*}{197} & \multirow{3}{*}{250} & \multirow{3}{*}{1} & \multirow{3}{*}{2} & \multirow{3}{*}{4} & \multirow{3}{*}{5} & \multirow{3}{*}{6} & $99 \mathrm{~cm}$ & $311 \mathrm{~cm}$ & & \\
\hline & & & & & & & Canol & meter & \multirow[t]{2}{*}{ Canopy status: } & heavily truncated, branches \\
\hline & & & & & & & & & & bending to the ground \\
\hline Distance & Comme & & $\mathrm{mi}$ & tlet & ee, sl & hoo & & & & \\
\hline & Place o & rtag: & at & he b & otto & $\mathrm{m}$ & the left & & & \\
\hline
\end{tabular}

The next step in the tree survey was the digitalization, where we aimed at the creation of such an overall (extendable and updateable) map database, which can be used for traditional (tabular) and map (polling) analyses for the planning of the reconstruction steps and schedule but would also be helpful for future maintenance. A significant role of the database is that it enables the documentation of the single stages of the reconstruction and the further management. For all this, a correct mapping was necessary, thus - in lack of a geodetic survey - we geo-referred the point-like entities to an aerial photo and placed all that into the Unified National Projection System (EOV) used in Hungary. This way this geoinformatic database can be confronted with earlier cartographic sources, so it can offer a basis for historical research. The major steps of the digitalization were the organization of the completed cadastre into a database of an appropriate structure, the insertion of the aerial photo with coordinates, the search for characteristic specimens and with their help the matching of the numbered points to the photo, finally the combination of the two systems. All this and the following data analysis have been carried out with the help of the MapInfo software for geoinformatics (Bede-Fazekas, 2011).

During the analysis we created thematic map sheets and the distributions according to the significant data were illustrated with diagrams (Fig. 8). 


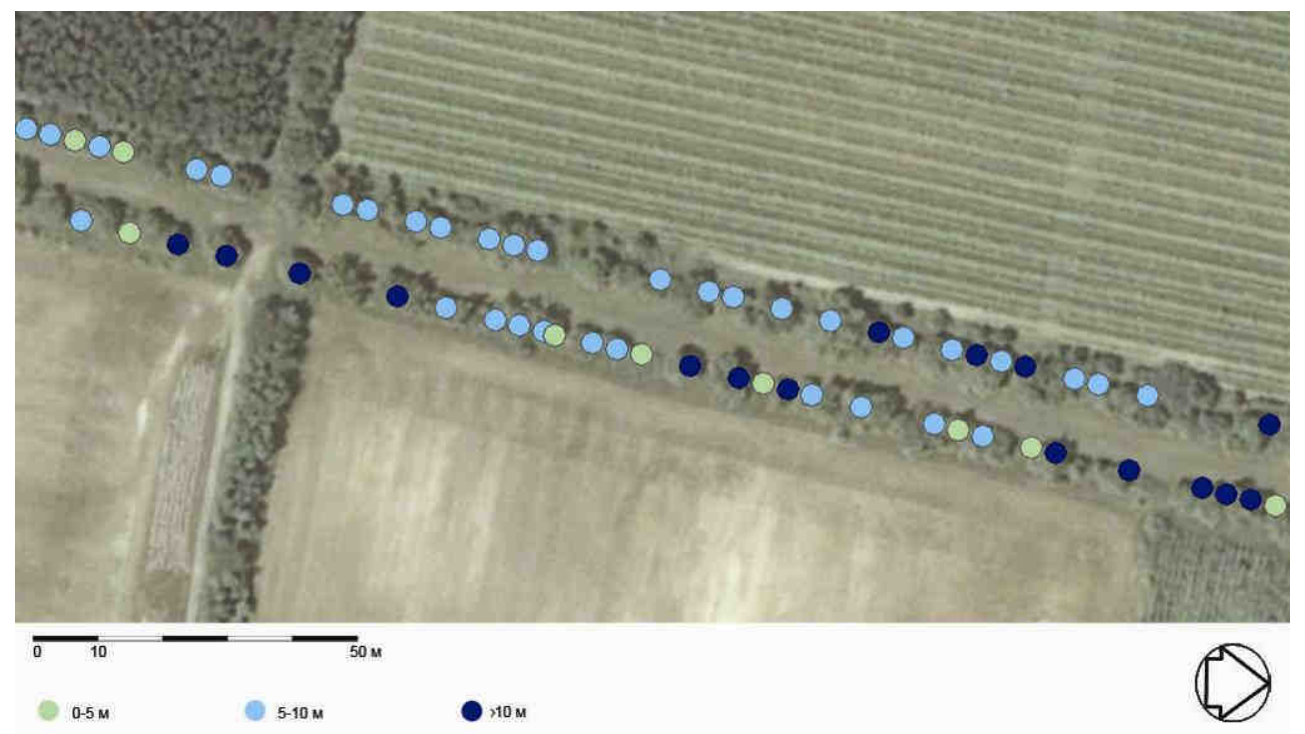

Figure 8. One of the thematic map sheets of the allée divided into six segments, where we have regrouped the specimens standing at their original place into three categories based on to the canopy-diameter

\section{Results}

From the surveyed 581 original spots altogether there are 327 originally planted living trees, the number of the inter-plantations is 193. Altogether we found 167 dead and 280 young specimens, certainly not planted at the outset, but they might have been renewed through the shoots of the original ones (Fig. 9). The inter-plantations occurred primordially in the southern segment.

$$
\square \text { young } \quad \text { old } \square \text { decayed }
$$

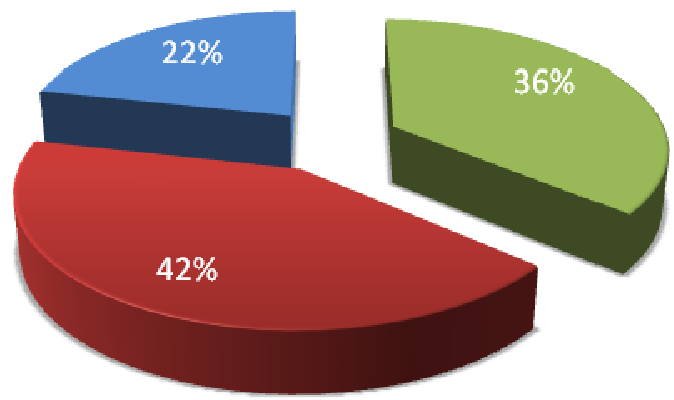

Figure 9. The distribution of the (250 years) old, the young and the decayed specimens in the cadastre

Interesting information of the age distribution is that $59 \%$ of the stand is from the original plantation, nevertheless only $1 \%$ is over 100 years, but under 250 . Thus it can be stated about only a few specimens that they are of a late plantation. The trees between 41 and 100 (which are mostly the renewals from old ones through their shoots, thus genetically not uninteresting) make up for $5 \%$ of the whole stand, $29 \%$ of the trees is 11-40 years old, 6\% 0-10 years old (Fig. 10). The distribution shows well that in the last years the need for the renewal of the allée has become obvious, which has been 
carried out, in default of overall, long-term objectives (requiring drastic interventions) mainly with the planting of young saplings. On the southern segment there are more recently planted young specimens, but most of them are planted with an intermediate spacing. The odd (western) side shows a much more varied age distribution.

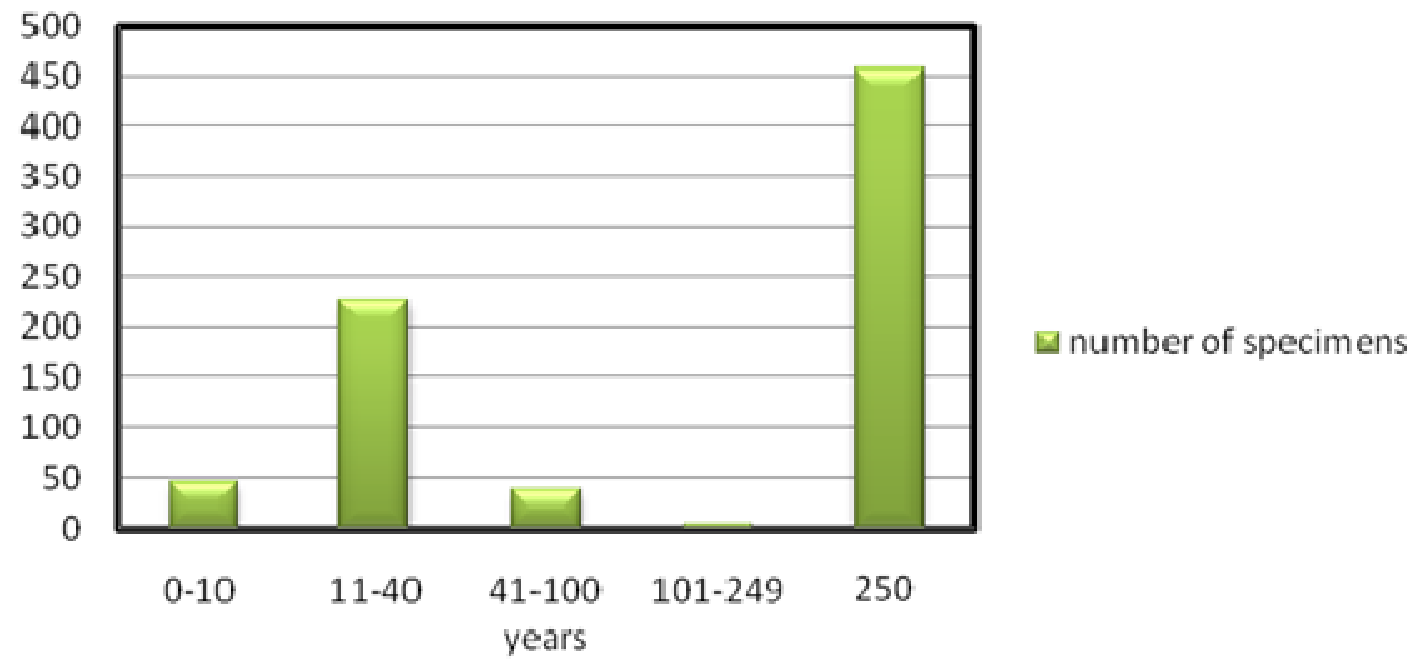

Figure 10. The estimated age distribution of the inventoried trees. The category of 250 years also includes the already decayed trees (129 out of 456). The diagram also shows well the acceleration of the decaying of the original specimens.

From the health status distribution it is important to highlight that the specimens classified into (the most valuable) category 1 make up for $10 \%$ of the whole stand. We have found an extremely high number of specimens in good condition north from the railway embankment (on both sides) and on the final segment (odd side). Beyond these the allée has a very mixed composition with respect to health condition, most specimens can be classified into the categories 2 and 4 (Fig. 11).

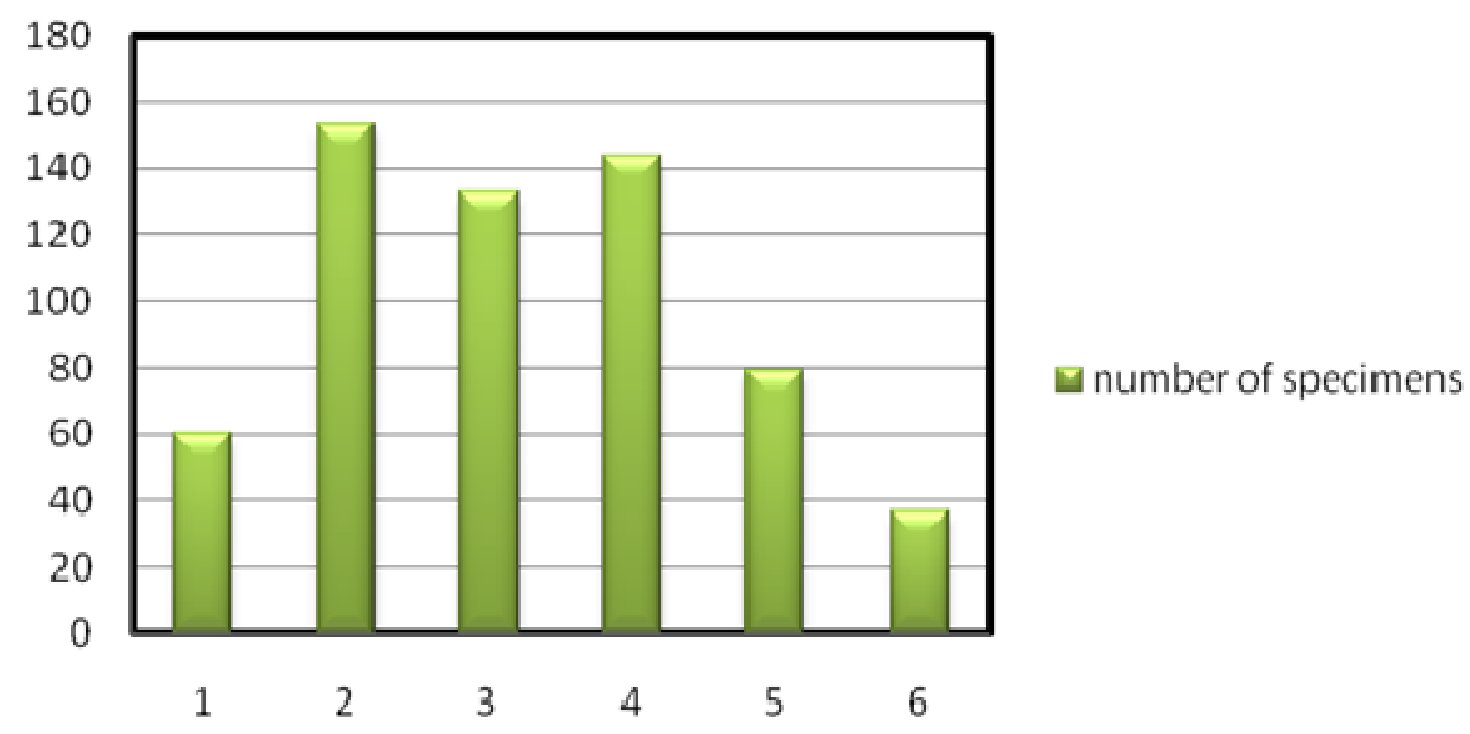

Figure 11. Distribution of the six health status categories (meanings of the categories can be found in Table 1) 
The specimens with a canopy diameter under $5 \mathrm{~m}$ (young plants and suppressed specimens) account for $57 \%$ of the stand, while $14 \%$ of the surveyed trees had grown a canopy wider than $10.5 \mathrm{~m}$. The majority of the latter acts as a solitary plant, growing in an open space, since its neighbours decayed or got covered by them (Fig. 12). 5\% (37 specimens) of the complete strand grew a trunk with a diameter over $1 \mathrm{~m}$. For the future reconstruction planning we have also prepared analyzing map sheets where we have also indicated the old, healthy specimens (classified into categories 1,2,3) standing at their original spot. The substitution of these is the least urgent, thus their distribution is not uninteresting.

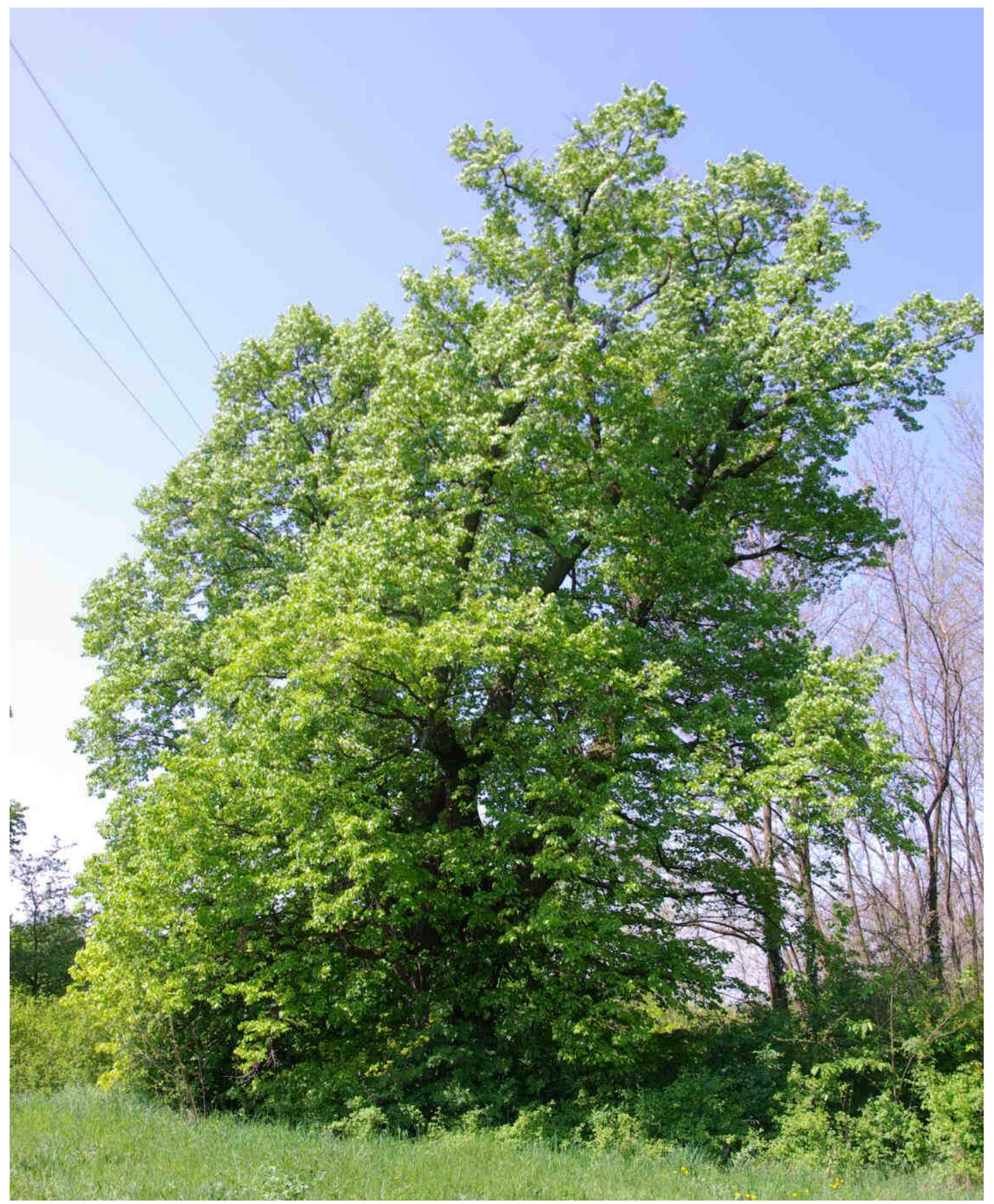

Figure 12. The neighbours died, so the No. 197 is growing as a solitary specimen (photo: L. Gerzson) 
It is important to highlight that south from the railway embankment, on the odd side we can find valuable specimens in large numbers, but next to the forest patches planted close to the allée, the old, healthy specimens are almost completely missing (Fig. 13), which can be explained by the disappearance of the open spacing and the free aeration in these segments. On the other areas we can mostly find a scattered distribution which does not underpin the idea of the spatially segmented renewal. The combined reconstruction lends itself as a possible alternative, by which the large part of the allée would be renewed in segments, but these tree specimens of good condition would remain as solitaries until the last planting operation of the allee-renewal, or until their unavoidable final decay.

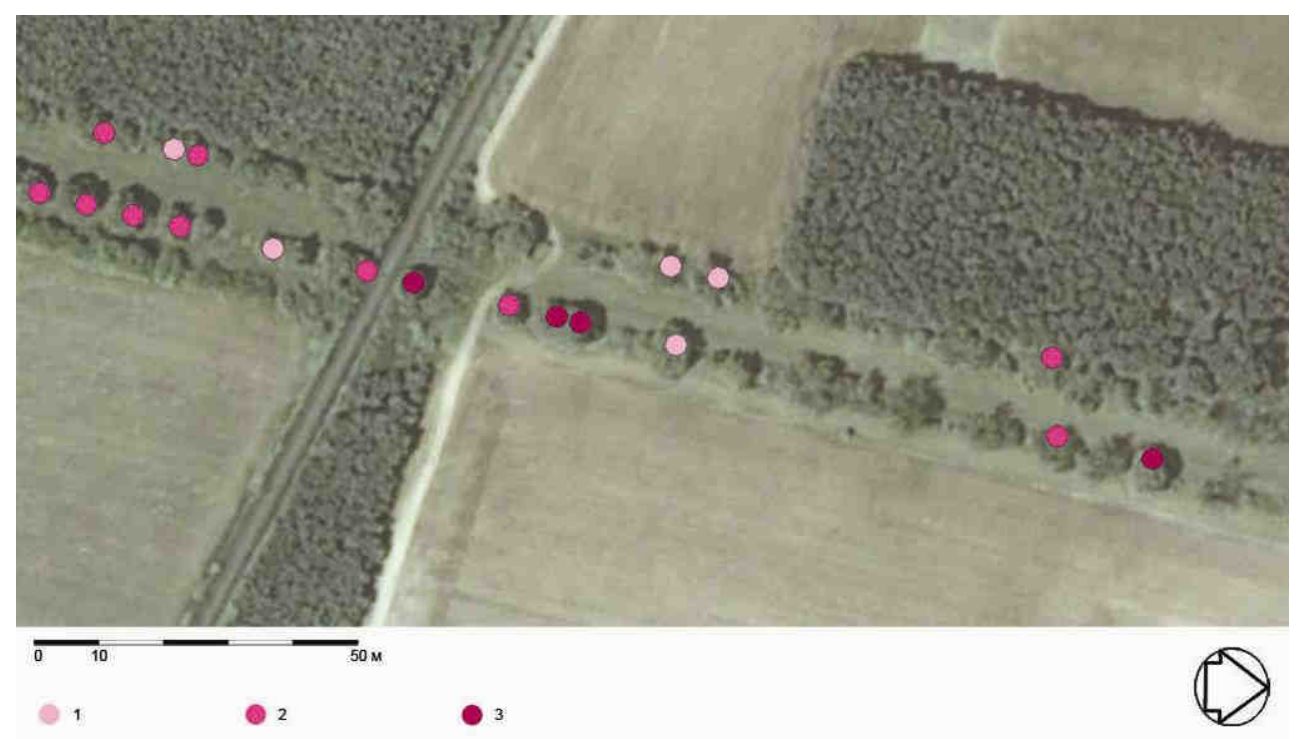

Figure 13. We projected the originally planted species of good condition (health status categories 1,2,3) on the aerial photo on this map sheet. Next to the oak patch on the northwest, there are but a few vital specimens, since this forest grew too tight on the allee.

The analyses made it obvious that the allée, looking vital at the first sight, in reality decays continuously and at a very rapid pace (Fig. 14), so the removal of the trees' shoots, the cutting back of the branch system of certain specimens and the clearing of the trees' environment is a desperately urgent task. The limes tend to grow root shoots and stem shoots. Thus the removal of the shoots should be part of the usual yearly maintenance. This is easy to do with young shoots, along with the mowing of the lawn. This same question could be solved by pasturage as well. However, the removal of the now visible 5-10 years old shoots, often of a size of a smaller tree, is a serious task which has to be carried out with the appropriate precision (not too deep, nor to high). The shoots accelerate the weakening and decaying of the old trees, since the roots supply nutrients more easily to the shoots that are spaced closer and have young, healthy conducting tissues, than to the shoot tips in the canopy where they have to press them through the century-old tightened tissues. 


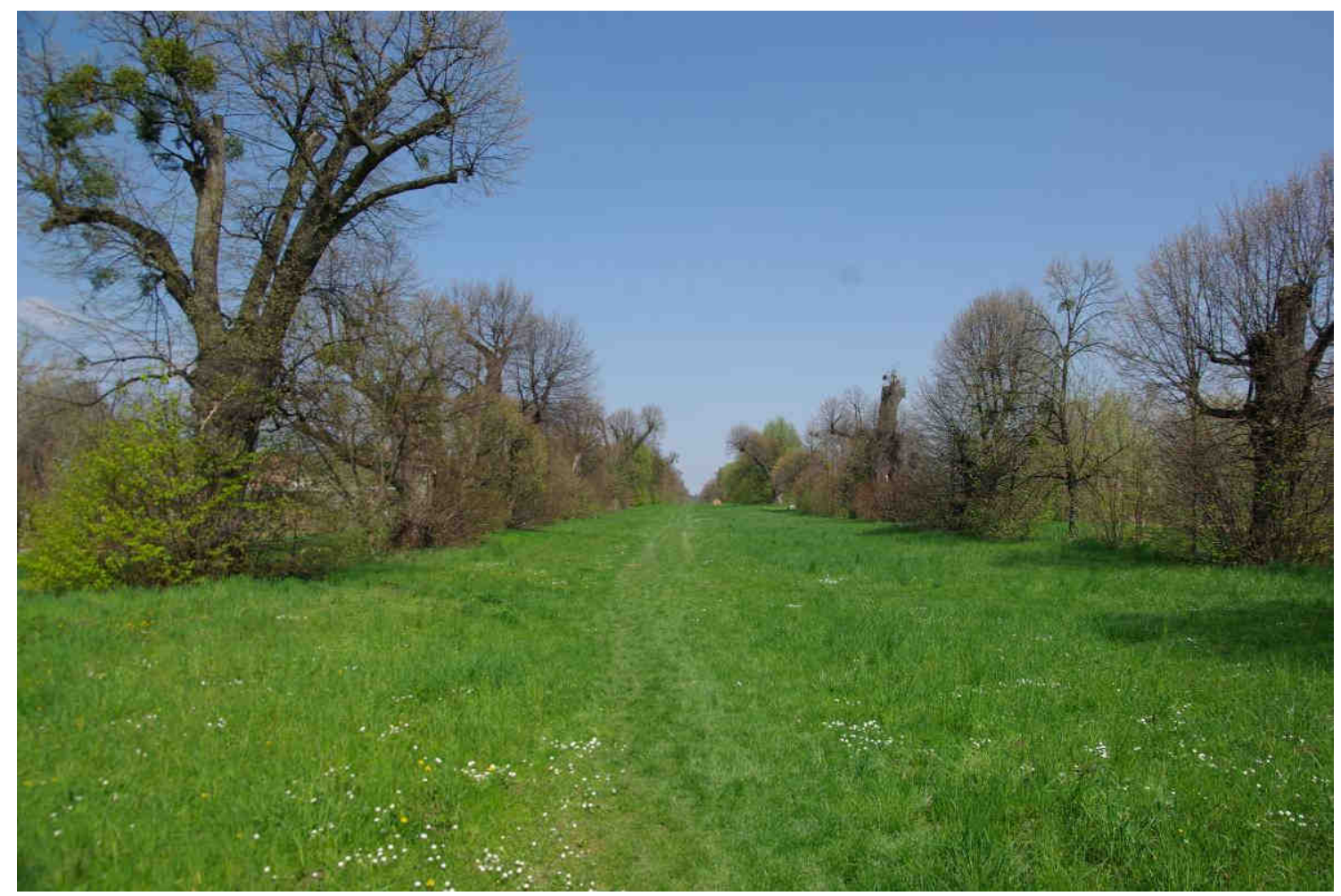

Figure 14. Before spring braird it is easy to see that the branch system of the old trees is without exception heavily truncated and constantly decaying. (photo: L. Gerzson)

It is also a matter of urgency to clear out the various weed trees and especially to suppress the aggressively expanding forest growing onto the allee at places. The different planted forest patches - of acacia, sessile oak, turkey and sessile oak - at certain segments completely grew onto the allée and almost completely surrounded the trees of the allée at some places.

In 2012 the nursery propagation of the inventoried specimens from the original plantation has to be initiated. From every single specimen planted at the establishment of the allee 20-30 pieces of vegetative propagated offspring have to be produced in the nursery designated for this purpose. This is necessary so that in the future we can substitute the old specimens by their own progeny. We need a quite large number of progeny because during the several years long nursery raising the young trees might decay, get deformed, and all the specimens that are left over, as a so called surplus, can be sold at an elevated price due to their special ideal value (Gerzson, 2011).

The replacement of the allee can be done in one step or in stages. For the substitution conducted in one phase it is necessary to designate a final deadline based on a merely professional planning (on our opinion around 20-25 years), by which the complete replacement has to be carried out. By then, the previously propagated specimens in the nursery cold grow into substantial trees and could lend themselves for the substitution. This will probably meet a high resistance from many sides, so it can only be realized after a very profound and broad agreement. The other possible solution is to continuously substitute only the trees that just decayed or are close to derogation. Since the plantations at different times occur with trees of the same age and development stage, after the plantation - even if it takes decades - we would finally get a uniform allée, even though the nursery specimens which are replanted every 4-5 years develop 
more slowly than the ones growing undisturbed at their final position. In this case we will need to take care of the propagated specimens, their nursery maintenance and protection for decades (Gerzson and Szilágyi, 2011a).

The nursery growing of the trees might raise a number of questions. Since we are talking about a seedling population, it might happen that the growth vigour of the propagated clones will be very different. This is why, from a purely practical point of view, we need to look at the possibility of a renewal of the allée only based on the clones of some (5-15) old trees. This solution would of course significantly reduce the ideality behind the principle that says that by replacing the original trees with their own clones we could provide for certain continuity in the renewal of this value which we inherited from the historical past. Taking it further, an even more practical solution would be to use the vegetative propagated clones of one single specimen - the one with the nicest form and the best characteristics - to grow all trees for the replacement of the complete allée. This solution would result in the most uniform allée but in this case that might not be the most important priority (Gerzson and Szilágyi, 2011b)!

\section{Discussion}

The above outlined several decades long renewal program can only be imagined with a social and institutional collaboration. As a first step therefore the consultative board of the competent, the stakeholders and the experts need to be set up, the members, supporting members and seconders of which would come from the experts elaborating the allée renewal methodology, from the Academy founded by István Széchenyi, the managing Practicing Forestry, the competent (local and county) municipalities and main authorities (ministries, heritage and nature conservation inspectorate, national parks directorate). This panel (Consultative Board for the Széchenyi Lime Tree Allée) could perform its task after the approval of the renewal concept in the framework of the elaboration of a long-term action plan (for 20-30 years), then by directing and controlling its implementation. The above outlined reconstruction proposal is, due to its scale and the mentioned long time period an extraordinarily costly enterprise. This is why it is necessary that the association to be created works as a high level cooperation and assures the complete implementation of this enormous task with an accurate cost analysis and by finding the right funds. In this project, half-measures, half-completed plans would result in an impermissible loss of value.

The guideline of the renewal program was to safeguard and transmit the spiritual and genetic heritage manifested in the decaying, but still grandiose trees. By the vegetative propagation of the "historical tree stock" we can preserve and transmit an ornamental tree stand of a proven long lifetime. In Hungary no similar authentic allée renewal has taken place yet and we can't find any renewal of such scale and of such spiritualcultural and scientific value neither among the examples abroad. We are convinced that the above outlined renewal methodology is a program that comes up to the remembrance of the Széchenyi family.

Acknowledgements. The financing of the research was supported by the TÁMOP-4.2.1/B-09/1/KMR2010-0005 program. 


\section{REFERENCES}

[1] Bede-Fazekas Á. (2011): A nagycenki hársfasor felvételezése és állapotának értékelése. Workshop, Nagycenk (ppt presentation).

[2] Csima P., Módosné Bugyi I. (2003): A nagycenki hársfasor természetvédelmi kezelési terve. - In: Csemez, A. (ed) Száz éve született Ormos Imre. Szent István Egyetem Tájépítészeti, -védelmi és -fejlesztési Kar. Budapest. p.73-84.

[3] Földváry M. (1934): A nagycenki rezerváció és hársfasor. - Erdészeti Lapok 73(7): 597.

[4] Gerzson L. (2011): A nagycenki hársfasor megújításának lehetőségei és módszertana. Workshop, Nagycenk (ppt presentation).

[5] Gerzson L., Szilágyi K. (2011a): Egy pusztuló műemlék - A nagycenki hársfasor megújításra vár. - Mủemlékvédelem 15(1): 46-56.

[6] Gerzson L., Szilágyi K. (2011b): Gondolatok a nagycenki hársfasor állapotáról és megújításának lehetőségeiről. - 4D 6(21): 2-19.

[7] Kelemen I. (2011): Adatok a cenki kastélykápolna és remeteség történetéhez. - Soproni szemle, A Széchenyi család nemzedékei. 2011(2): 149.

[8] Örsi K. (1976): Nagycenk építéstörténete. - Műemlékvédelem (20): 6.

[9] Örsi K. (1992): Történeti kertek - A magyar kertépítészet legszebb alkotásai. - Ökotáj Kert (2): 6.

[10] Rapaics R. (1940): Magyar kertek. - Reprint: 1993, Magyar Könyvbarátok, Budapest.

[11] Rotenstein, G.E. (1783): Reisen durch einen Theil des Königreichs Ungarn, im 1763sten und folgenden Jahren. Erster Abschnitt. - In: Bernoulli, Johann: Sammlung kurzer Reisebeschreibungen und anderer zur Erweiterung der Länder- und Menschenkenntniß dienender Nachrichten. IX. Bey dem Herausgeber, Berlin-Leipzig.

[12] Soó R. (1973): A magyar flóra és vegetáció rendszertani-növényföldrajzi kézikönyve V. - Akadémiai Kiadó, Budapest. 